\title{
A Novel Route for the Synthesis of Mesoporous and Low-Thermal Stability Materials by Coupled Dissolution- Reprecipitation Reactions: Mimicking Hydrothermal Mineral Formation
}

\author{
Joël Brugger ${ }^{\star a b}$, Aoife McFadden ${ }^{\mathrm{ac}}$, Claire E. Lenehan ${ }^{\mathrm{c}}$, Barbara Etschmann ${ }^{\mathrm{ab}}$, Fang Xia ${ }^{\mathrm{ab}}$, \\ Jing Zhao ad, and Allan Pringabc
}

\begin{abstract}
Replacement reactions ('pseudomorphism') commonly occur in Nature under a large range of conditions ( $\mathrm{T} 25$ to $>600{ }^{\circ} \mathrm{C}$; $\mathrm{P} 1$ to $>5 \mathrm{kbar}$ ). Whilst mineral replacement reactions are often assumed to proceed by solid-state diffusion of the metal ions through the mineral, many actually proceed via a coupled dissolution and reprecipitation (CDR) mechanism. In such cases, a starting mineral is dissolved into a fluid and this dissolution is coupled with the precipitation of a replacement phase across the reaction front. In cases where there are close relationships between the crystal structures of the parent and newly formed minerals, the replacement can be topotactic (interface-coupled dissolution and reprecipitation). The kinetics and chemistry of the CDR route are fundamentally different from solid-state diffusion and can be exploited i) for the synthesis of materials that are often difficult to synthesise via traditional methods and ii) to obtain materials with unique properties. This review highlights recent research into the use of CDR for such synthetic challenges. Emphasis has been given to i) the use of CDR to synthesise compounds with relatively low thermal stability such as the thiospinel mineral violarite $\left((\mathrm{Ni}, \mathrm{Fe})_{3} \mathrm{~S}_{4}\right)$, ii) preliminary work into use of CDR for the production of roquesite $\left(\mathrm{CulnS}_{2}\right)$, a potentially important photovoltaic component and, iii) examples where the textures resulting from CDR reactions are controlled by the nature and texture of the parent phase and the reaction conditions; these being the formation of micro-porous gold and three-dimensional ordered arrays of nanozeolite of uniform size and crystallographic orientation.
\end{abstract}

Keywords: Copper-indium sulphide · Coupled dissolution reprecipitation reaction · Materials synthesis . Mineral replacement $\cdot$ Nanozeolites $\cdot$ Porous gold $\cdot$ Thiospinels

\section{Introduction}

Aqueous fluids are ubiquitous in the Earth's crust and are the most important medium for mineral formation in surface and near-surface environments. Therefore understanding the dissolution, transport, and deposition of metals in aqueous hydro-

${ }^{*}$ Correspondence: Dr. J. Brugger ${ }^{a b}$

E-mail: joel.brugger@samuseum.sa.gov.au

aDepartment of Mineralogy

South Australian Museum

North Terrace, Adelaide

SA 5000, Australia

'TRaX, School of Earth and Environmental Sciences University of Adelaide, Adelaide, SA 5005, Australia 'School of Chemical and Physical Sciences Flinders University

GPO Box 2100 Adelaide, SA 5001, Australia

'School of Chemical Engineering

University of Adelaide, Adelaide, SA 5005, Australia thermal fluids is central to understanding mineral genesis in geology. Minerals, and in particular, ores, form over a wide range of hydrothermal conditions: pressures from ambient to $>5 \mathrm{kbar}$, temperatures from ambient to $>600{ }^{\circ} \mathrm{C}$, and complex solvent compositions (e.g. salinity up to $>50 \mathrm{wt} \%$ salt; varying amounts of volatiles such as $\mathrm{CO}_{2}, \mathrm{CH}_{4}$ or $\mathrm{H}_{2} \mathrm{~S}$ ) and provide the World's supply of metals such as $\mathrm{Au}, \mathrm{Ag}, \mathrm{U}, \mathrm{Pb}$, $\mathrm{Zn}$, Mo or Fe. ${ }^{[1]}$ In most cases minerals are not deposited into open cavities, but deep underground where reactions proceed via replacement of pre-existing rock-forming minerals. In this process the existing set of minerals reacts with the hydrothermal fluid and a different assemblage of minerals forms. In these processes, the external dimension of the primary mineral is preserved by the mineral product in varying degrees of detail, a widespread phenomenon called pseudomorphism. At a fundamental level, understanding processes such as metasomatism, metamorphism, or ore formation requires understanding the interplay between the physical chemistry of mineral dissolution and crystallization, so- lution chemistry, and fluid transport along grain boundaries and through the porosity within minerals. Much research effort has recently been focused on the formation of minerals by replacement via a fluid phase, a mechanism known as coupled dissolution-reprecipitation reaction (CDR). ${ }^{[2,3]}$ The nature of fluid-mediated replacement reactions was explored by Cardew and Davey ${ }^{[4]}$ in polymorphic transformation where there is no change in chemistry. Such topotactic reactions have sometimes been called structure-inheriting solid-state reactions (SISSRs) under hydrothermal conditions, ${ }^{[5,6]}$ but were recently shown to represent a special form of CDR reactions known as interface coupled dissolution-reprecipitation reactions (ICDR reactions). ${ }^{[7]}$ In ICDR reactions, dissolution of the precursor mineral is coupled both in space and time with the precipitation of the product mineral, allowing the external dimension to be preserved.

Our recent research into the nature of CDR reactions has led us to believe that these reactions can be employed in some forms of materials synthesis where more 
direct methods are difficult. A suitable precursor is prepared, then partially, or completely, replaced from the grain surface into the interior via a CDR reaction in a carefully designed hydrothermal fluid to yield the product. In many respects these CDR reactions are similar to a process known to metallurgists as dealloying, which is used to produce nanoporous metals. ${ }^{[8]}$ Indeed, ICDR reactions can also lead to the synthesis of materials with remarkable textural properties. Here we review ICDR as a reaction mechanism, and emphasize how the unique properties of this reaction mechanism can be used in materials synthesis.

\section{The Mechanism of Interface Coupled Dissolution- Reprecipitation Reactions}

While solid-state reactions are controlled by diffusion ( $\mathrm{P}, \mathrm{T}$, stress state), CDR reactions proceed via the complete dissolution of the parent phase into a fluid, coupled (in space and time) with the precipitation of the product at the reaction front. Specific features of CDR reactions - especially in contrast with solid-state reactions - include i) the variable length scale of coupling, i.e. the distance between the dissolution front and the site of precipitation, ii) the controls exerted by solution chemistry and temperature on reaction kinetics and product composition, iii) the sharp phase boundary between the precursor and the product, and iv) the porous texture of the product.

The replacement length scale can vary from $\sim 1 \mathrm{~nm}$ to up to 10 's of $\mu \mathrm{m}$ or more. ${ }^{[9,10]}$ The length scale of the coupling is controlled by the interplay between the kinetics of dissolution and precipitation, and these are in turn controlled by the relative solubilities of the parent and product phase, which depends on $\mathrm{P}, \mathrm{T}$, and solution composition (e.g. $\mathrm{pH}$, redox, ligand concentrations $\left.{ }^{[9]}\right)$; and by the kinetics of nucleation and growth of the product. Local chemical gradients near the reaction front may also play a role in controlling dissolution and precipitation rates; in all cases, however, the product must be porous and remain porous for the duration of the reaction in order to enable fluid transport to and from the reaction front. In natural minerals it appears that over time the porosity heals, or is annealed out. In the case of a tightly coupled reaction (nanometer length scale), the rate of precipitation of the product must be at least as fast as the dissolution of the parent phase. Some CDR reactions proceed topotactically, preserving both the crystallographic orientation and the external morphology of the replaced grain (ICDR), while in others crystallographic
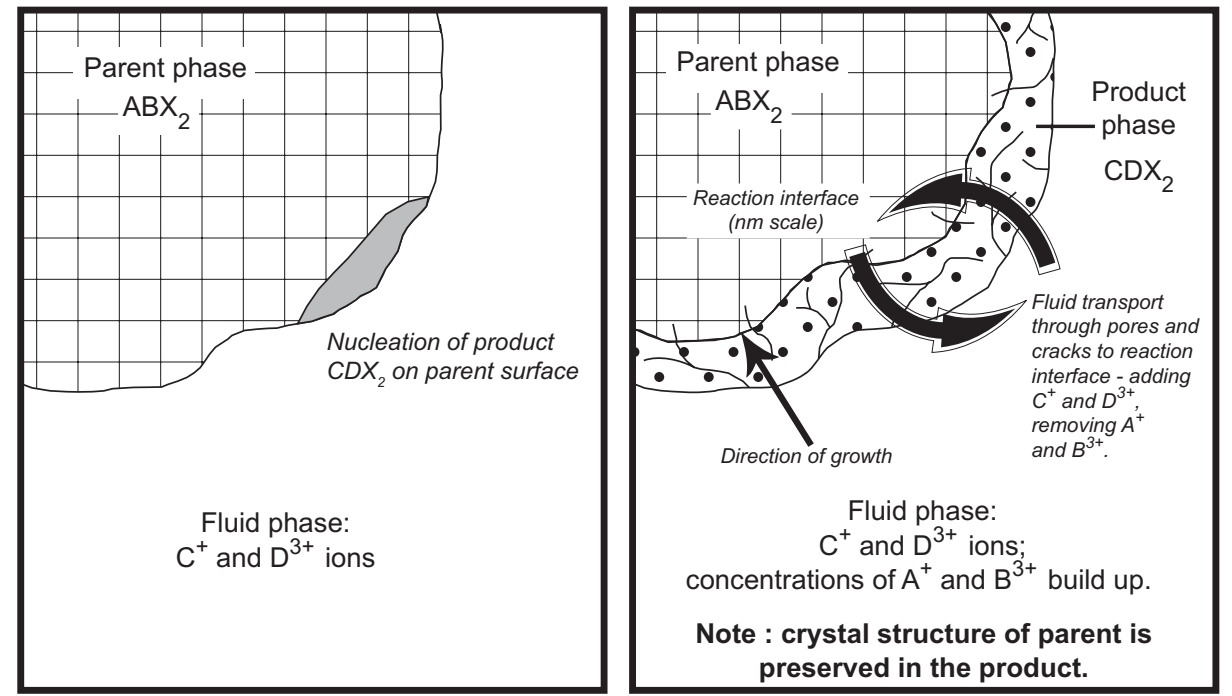

Fig. 1. Schematic diagram of an interface coupled dissolution-reprecipitation reaction.

relationships are not inherited. For crystallographic orientation to be preserved (Fig. 1 ), there must be a close structural relationship between the product and the parent phases, enabling the surface of the parent phase to serve as a patterning agent for the nucleation and growth of the product. ${ }^{[9]}$

\section{Examples of Materials Synthesis via ICDR Reactions}

\section{Synthesis of Thiospinels}

A class of metal sulphides, thiospinels $\left(\mathrm{M}_{3} \mathrm{~S}_{4}\right)$, analogues of oxide spinels, are attracting growing attention for their magnetic, semiconducting and superconducting properties as well as the metal-insulator transitions exhibited by some compositions. ${ }^{[11-13]}$ Syntheses of thiospinels are thus important to facilitate full characterization of their properties and the development of their industrial applications. ${ }^{[14]}$ Many metal sulphides can be readily synthesized by the traditional method of dry synthesis: heating the metal with elemental sulphur to high temperatures $\left(>500{ }^{\circ} \mathrm{C}\right)$ in an evacuated sealed glass tube. Others, however, are much more difficult to produce by this route because they have low thermal stabilities $\left(<500^{\circ} \mathrm{C}\right)$, and thus must be prepared at temperatures below their decomposition points. One such compound is the thiospinel mineral violarite, $(\mathrm{Ni}, \mathrm{Fe})_{3} \mathrm{~S}_{4}$, which breaks down at $373{ }^{\circ} \mathrm{C} .{ }^{[15]}$ Slow reaction rates limit the application of the traditional route to the synthesis of $(\mathrm{Ni}, \mathrm{Fe})_{3} \mathrm{~S}_{4}$, since several months annealing at or below $300{ }^{\circ} \mathrm{C}$ are required. In addition, the product obtained via dry synthesis always contains significant quantities of impurity phases such as nickeliferous pyrite $(\mathrm{Fe}, \mathrm{Ni}) \mathrm{S}_{2}{ }^{[16,17]}$ Exploring the potential of ICDR reactions to explain the common occurrence of violarite as an alteration product of pentlandite in nature, we were able to prepare pure samples of the thiospinels (Ni,Fe) $\mathrm{S}_{4}$ (violarite) and $\mathrm{Co}_{3} \mathrm{~S}_{4}$ (linnaeite) from $(\mathrm{Fe}, \mathrm{Ni})_{9} \mathrm{~S}_{8}$ (pentlandite) and $\mathrm{Co}_{9} \mathrm{~S}_{8}$ (cobaltpentlandite) precursors. ${ }^{[17,18]}$ In this case pentlandite and violarite both have structures based on cubic closed packed arrays of $\mathrm{S}$ atoms, but differ by the distributions of metals over the available interstitial octahedral and tetrahedral sites (Fig. 2).

Using an ICDR reaction, pure $(\mathrm{Ni}, \mathrm{Fe})_{3} \mathrm{~S}_{4}$ can be synthesized in less than three days, compared to the traditional dry synthesis route that requires three months annealing to obtain a product with only 72 $\pm 5 \mathrm{wt} \%$ purity. Xia et al. ${ }^{[9,18,19]}$ found that the $\mathrm{Fe} / \mathrm{Ni}$ ratio of $(\mathrm{Ni}, \mathrm{Fe})_{3} \mathrm{~S}_{4}$ could be adjusted by varying the reaction conditions, including temperature $\left(125-145^{\circ} \mathrm{C}\right), \mathrm{pH}$ (1 to 6), and precursor stoichiometry. Between $\mathrm{pH} 1$ and 6 the reaction proceeds via an ICDR reaction, with a very sharp reaction front and porous $(\mathrm{Ni}, \mathrm{Fe})_{3} \mathrm{~S}_{4}$ product, as the dissolution of the pentlandite precursor is rate-limiting (Fig. 3). However, at low $\mathrm{pH}(<1)$ the precipitation of violarite becomes rate-limiting and the reaction is no longer interface coupled. The difference in mechanisms is illustrated in Fig. 4. It is also important to note that violarite is not the thermodynamically stable phase with respect to the bulk solution composition, yet was the only $\mathrm{Fe}-\mathrm{Ni}$ sulphide forming under most experimental conditions; this reflects the fact that nucleation of violarite is favoured due to the close relationship with pentlandite. The role of the surface of the parent mineral in controlling the nature of the product during nucleation and growth has been recognized for example by Roy and Linnehan[20] (hydrothermal replacement of biogenic carbonates by phosphates), and is discussed in detail by Figlarz et al. ${ }^{[21]}$ for both solid-state and hydrothermal situations. 


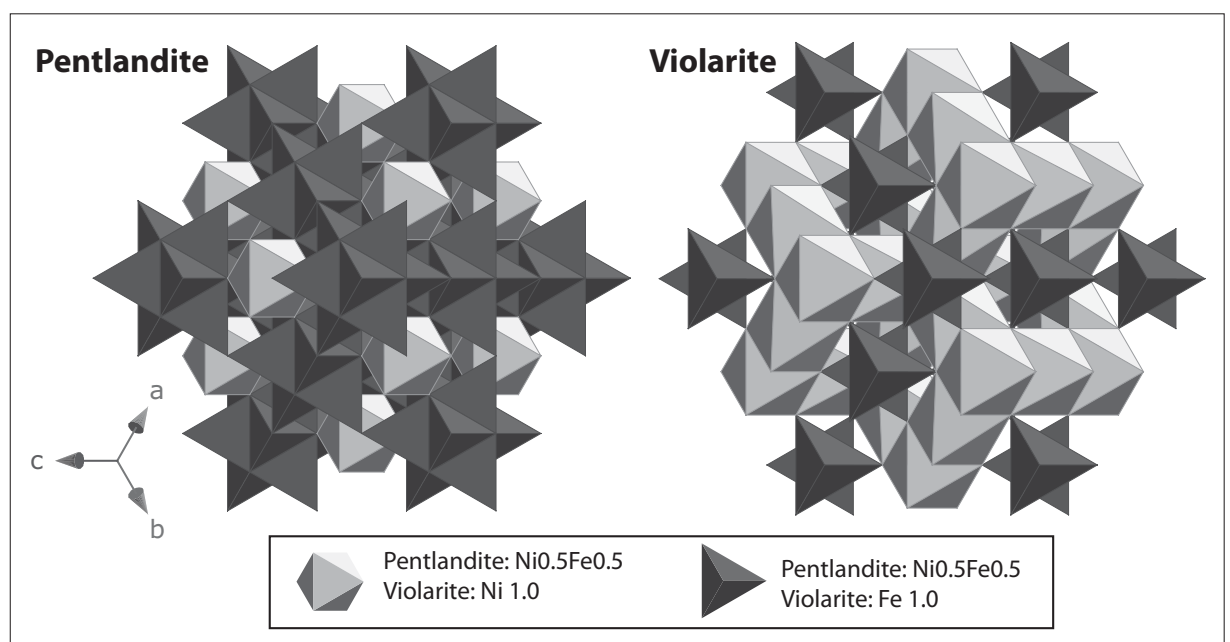

Fig. 2. Structural relationship between pentlandite and violarite, emphasizing the similarity in the close packed cubic arrays of $S$ atoms in both minerals. Projection on the (111) plane. In pentlandite, the metal atoms occupy $1 / 2$ of the tetrahedral sites and $1 / 8$ of the octahedral sites in the ccp $S$ array, while in violarite, they occupy $1 / 2$ of the octahedral sites and 1/8 of tetrahedral sites.
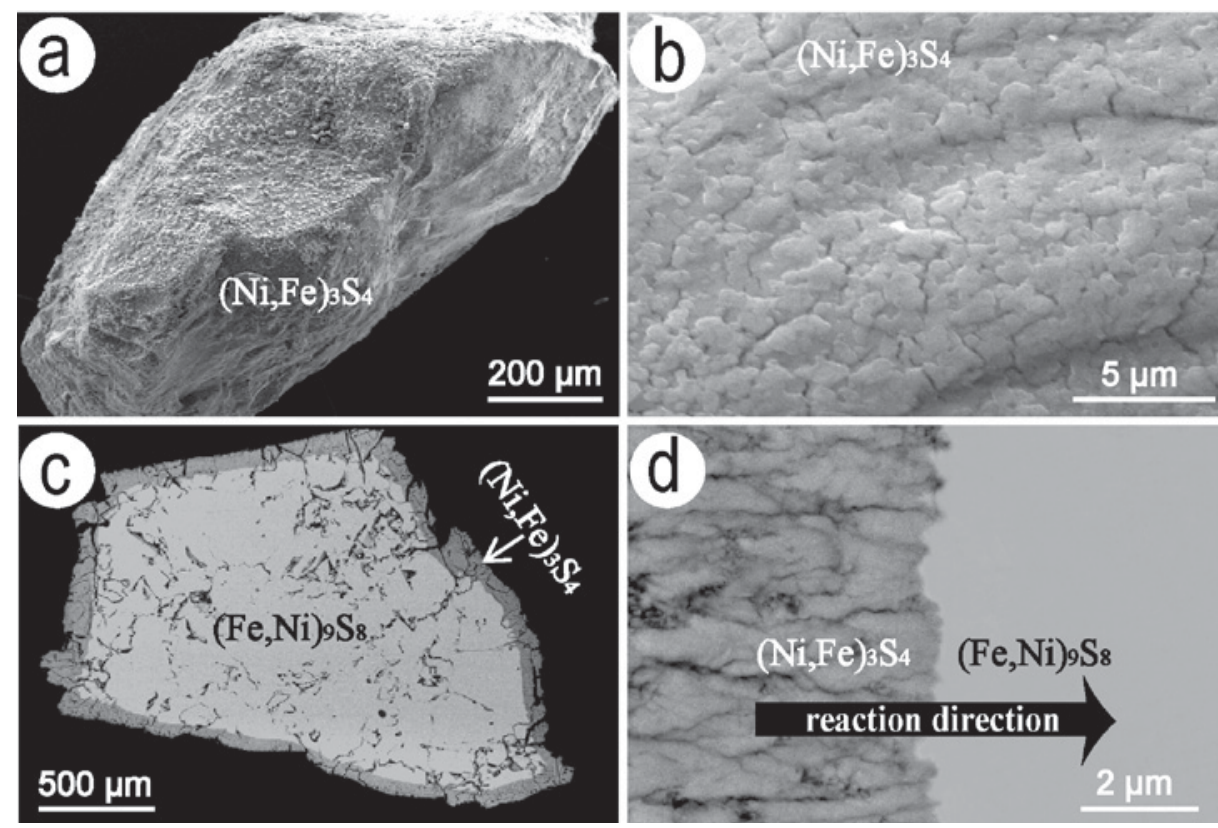

Fig. 3. SEM images of the pentlandite to violarite transformation. (a) SE image of a partially transformed pentlandite grain with a violarite outer layer. (b) SE image of porous violarite surface. (c) BSE image of cross section showing the advance of reaction from the grain surface to the interior and the preservation of external shape. (d) BSE image of the sharp reaction front and the direction of the transformation.

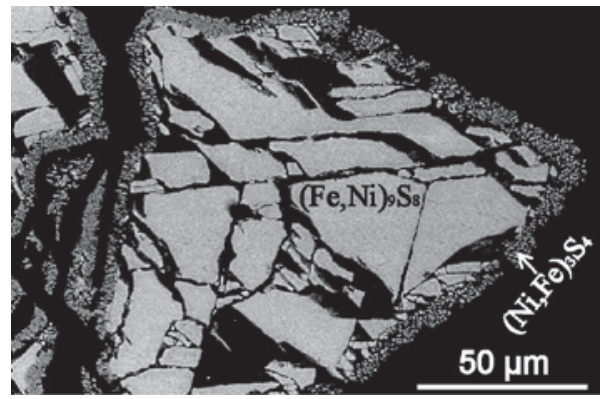

Fig. 4. SEM image of the replacement of pentlandite by violarite at low $\mathrm{pH}(\mathrm{pH}=1, \mathrm{~T}$ $=125^{\circ} \mathrm{C}$ ). Note that here the tight coupling between the dissolution and reprecipitation has broken down and the volarite only precipitates on the outside of the grain and not along the cracks or voids in the parent grain.

\section{Synthesis of Culns}

$\mathrm{CuInS}_{2}$ is a good semiconductor material with a direct band gap of approximately $1.5 \mathrm{eV}$ within the peak frequencies of the solar spectrum and a high absorption coefficient of approximately $2.65 \times 10^{5} \mathrm{~cm}^{-1}$. [22-24] Hence $\mathrm{CuInS}_{2}$ is an ideal material for use in photovoltaic devices such as solar panels, [24] with the added advantage of posing only a minimal toxicological threat to the environment. ${ }^{[25]} \mathrm{CuInS}_{2}$ occurs naturally as the rare mineral roquesite in high-temperature hydrothermal veins, usually in the form of inclusions in chalcopyrite $\left(\mathrm{CuFeS}_{2}\right)$, sphalerite $(\mathrm{ZnS})$ or bornite $\left(\mathrm{Cu}_{5} \mathrm{FeS}_{4}\right) \cdot{ }^{26]}$

Synthesis of $\mathrm{CuInS}_{2}$ has been achieved via a number of methods, including solid- state reaction, ${ }^{[27]}$ solvothermal synthesis, ${ }^{[28]}$ static hydrothermal synthesis, ${ }^{[29]}$ chemical vapour deposition[22,30,31] and spray pyrolysis. ${ }^{[32]}$ The application of $\mathrm{CuInS}_{2}$ in photovoltaic devices requires the production of pure, good quality thin films, ${ }^{[24]}$ but the cost of synthesis remains a major drawback for widespread use.[31]

Minerals such as chalcopyrite $\left(\mathrm{CuFeS}_{2}\right)$, bornite $\left(\mathrm{Cu}_{5} \mathrm{FeS}_{4}\right)$ and digenite $\left(\mathrm{Cu}_{9} \mathrm{~S}_{5}\right)$ are structurally related to $\mathrm{CuInS}_{2}$, exhibit semiconducting properties, ${ }^{[15,33]}$ and could be used as starting materials. Digenite for example has successfully been employed as a component in solar cells in the $\mathrm{CdS} /$ $\mathrm{Cu}_{9} \mathrm{~S}_{5}$ and $\mathrm{TiO}_{2} / \mathrm{Cu}_{9} \mathrm{~S}_{5}$ systems. ${ }^{[34,35]}$

We undertook a preliminary experimental study to see if we could deposit $\mathrm{CuInS}_{2}$ on the surface of either $\mathrm{CuFeS}_{2}$ or $\mathrm{Cu}_{9} \mathrm{~S}_{5}$ via ICDR under mild hydrothermal conditions. The synthesis was undertaken using an acetate buffered ( $\mathrm{pH} 3.8), 2 \mathrm{M}$ $\mathrm{NaCl}$ solution prepared using deoxygenated water. Dissolved in the solution were $\mathrm{In}(\mathrm{NO})_{3}(0.02 \mathrm{M}), \mathrm{FeSO}_{4} .7 \mathrm{H}_{2} 0(0.01 \mathrm{M})$ and $\mathrm{CuCl}(0.05 \mathrm{M})$, with either $\mathrm{CuFeS}_{2}$ or $\mathrm{Cu}_{9} \mathrm{~S}_{5}$ as the parent phase. CuInS $\mathrm{S}_{2}$ was successfully synthesised at $125{ }^{\circ} \mathrm{C}, 160{ }^{\circ} \mathrm{C}$ or $180{ }^{\circ} \mathrm{C}$. These results indicate that $\mathrm{Cu}_{0} \mathrm{~S}_{5}$ is a more pertinent starting material for the synthesis. Furthermore, the use of digenite $\left(\mathrm{Cu}_{0} \mathrm{~S}_{5}\right)$ eliminates the formation of the $\mathrm{Fe}_{2} \mathrm{O}_{3}$ by-product observed when using $\mathrm{CuFeS}_{2}$ as the starting material. Both products possessed a sharp reaction front and were finely cracked (Fig. 5), features that are typical of a coupled dissolution-reprecipitation reaction. Consequently both the transformation from $\mathrm{CuFeS}$ to $\mathrm{Cu}_{0} \mathrm{~S}_{5}$ and the further transformation of $\mathrm{Cu}_{9} \mathrm{~S}_{5}$ to $\mathrm{CuInS}_{2}$ proceeded by a CDR mechanism. The production of CuInS 2 was highly sensitive to solution chemistry, with the transformation from $\mathrm{Cu}_{9} \mathrm{~S}_{5}$ to $\mathrm{CuInS}_{2}$ proceeding only at low concentrations of $\mathrm{In}^{3+}$. Increasing $\mathrm{In}^{3+}$ concentrations above $0.02 \mathrm{M}$ led to $\mathrm{In}(\mathrm{OH})_{3}$ precipitation and inhibited the formation of CuInS, ${ }^{[36]}$ Further experimental work on the system is required to tune the solution conditions in order to produce homogenous thin films of $\mathrm{CuInS}_{2}$ on a $\mathrm{Cu}_{9} \mathrm{~S}_{5}$ matrix before the suitability of this method can be fully assessed.

\section{Engineering Microtextures by Interface Coupled Dissolution- Reprecipitation Reactions}

\section{Porous Gold from AuTe,}

Gold tellurides such as calaverite (Au$\mathrm{Te}_{2}$ ) are important Au carriers in some ore deposits, but are difficult to recover using common leaching methods. ${ }^{[37]}$ Zhao and coworkers ${ }^{[38,39]}$ found that Te could be effectively 'leached' from calaverite under hydrothermal conditions, leaving sponge- 

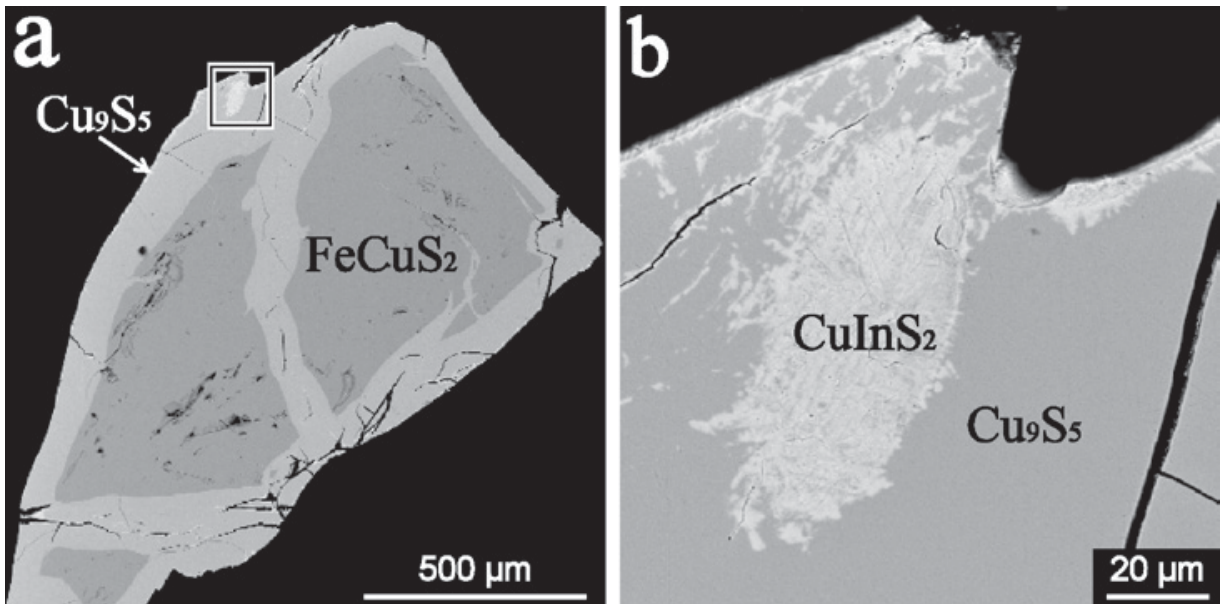

Fig. 5. SEM BSE Image of the $\mathrm{CuFeS}_{2}$ transformation to $\mathrm{Cu}_{9} \mathrm{~S}_{5}$ then further to $\mathrm{CulnS}_{2}\left(\mathrm{~T}=150^{\circ} \mathrm{C}, \mathrm{pH}\right.$ 3.8). (a) Grain of CuFeS2 partially transformed into $\mathrm{Cu}_{9} \mathrm{~S}_{5}$, with a minor amount of CulnS $\mathrm{S}_{2}$ present at the rim. (b) Detail of the transformation of $\mathrm{Cu}_{5} \mathrm{~S}_{9}$ into $\mathrm{CulnS}_{2}$ at the rim of the grain shown in (a).
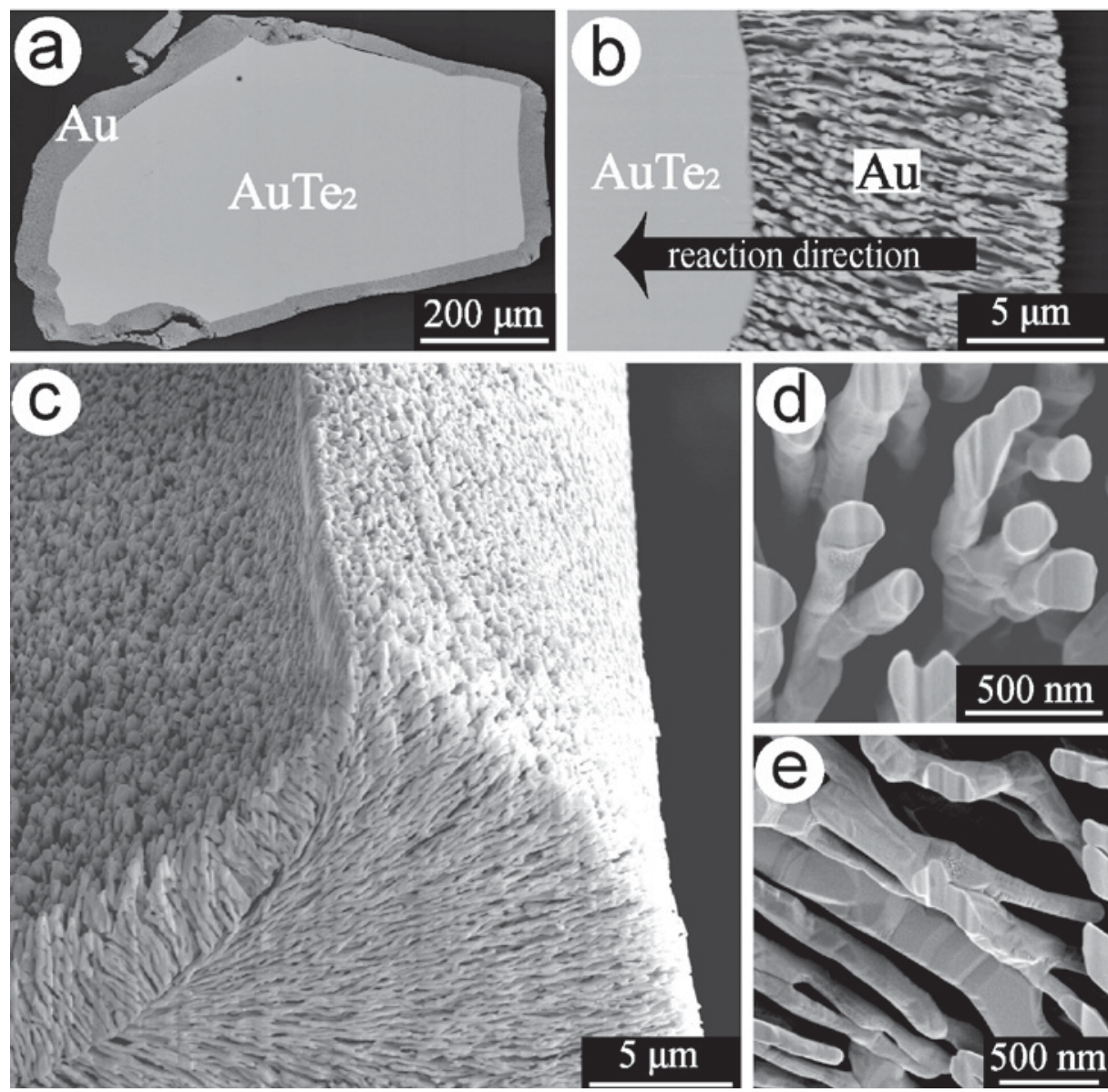

Fig. 6. SEM images of the transformation from calaverite to gold. (a,b) BSE images of partially transformed calaverite, showing the reaction direction, and the porous and filament-shaped gold aggregates growing from the sharp reaction interface. (c) SE images of a corner of a porous gold product. $(\mathrm{d}, \mathrm{e})$ Focused lon Beam milled gold phase clearly show the size and shape of the gold filaments.

like porous gold (Fig. 6). The reaction proceeded over a wide range of solution conditions ( $\mathrm{pH} 2-12)$, oxidant concentration and temperatures ( 140 to $220^{\circ} \mathrm{C}$ ). The replacement was pseudomorphic, with the porous gold preserving the external dimensions of the calaverite grains (Fig. 6a and 6b). The resulting elemental gold is porous, consist- ing of filament-shaped aggregates with diameters ranging from 200 to $500 \mathrm{~nm}$ and lengths up to $25 \mu \mathrm{m}$ (Fig. 6d and 6e). Gold crystals are randomly oriented with respect to the twinned calaverite grains.

The pseudomorphic transformation proceeds via a coupled calaverite dissolution-gold precipitation mechanism, with calaverite dissolution being rate-limiting relative to gold precipitation. Tellurium is lost to the bulk solution as Te(IV) complexes, and may further precipitate away from the dissolution site (e.g. autoclave walls) as $\mathrm{TeO}_{2}(\mathrm{~s})$. In contrast, gold precipitates locally near the calaverite dissolution site. Such local gold precipitation is facilitated by fast heterogeneous nucleation onto the calaverite surface. The dissolution of calaverite and the overall reaction are oxidation reactions, and oxygen diffusion through the porous metallic gold layer probably plays an important role in sustaining the reaction.

A similar dissolution-reprecipitation process may be responsible for the formation of 'mustard gold' during the weathering of gold-telluride ores. At $220^{\circ} \mathrm{C}$, solidstate replacement of calaverite by gold is slow (months), but calaverite grains $\sim 100$ $\mu \mathrm{m}$ in size are fully replaced in less than 24 hours under hydrothermal conditions, providing a possible alternative to roasting as a pre-treatment of telluride-rich gold ores.

\section{Transformation of Leucite (KAISi $\left.{ }_{2} \mathrm{O}_{\theta}\right)$ to Analcite ( $\left.\mathrm{NaAlSi} \mathrm{O}_{6^{*}} \mathrm{H}_{2} \mathrm{O}\right)$}

Zeolites and zeolite-like materials display unique molecular sieve structures and are often considered 'green' materials. ${ }^{[40]}$ Consequently, considerable research efforts are dedicated to the design of novel routes for the preparation of zeolites with hierarchical pore structures, adjustable size and morphology, uniform crystallographic orientation, and ordered arrangement, ${ }^{[41-43]}$ as these features are essential for emerging applications as advanced catalysts, chemical sensors, highly selective membranes, optical materials, and low dielectric materials for microelectronics. ${ }^{[44,45]}$

Great success has been achieved on the control of hierarchical pore structure, size, and morphology of zeolite products $^{[43,46,47]}$ yet relatively less progress has been made on the alignment of the nanoor micro-zeolites into uniformly oriented and/or highly ordered arrays. ${ }^{[48]} \mathrm{Xia}$ et $a l .{ }^{[49]}$ reported the first synthesis of $3 \mathrm{D}$ ordered arrays of nanozeolites with uniform size and crystallographic orientation, and adjustable overall shape by a simple hydrothermal coupled dissolution-reprecipitation pseudomorphic replacement route (Fig. 7). The key to synthesize 3D ordered arrays of nanocrystals with uniform size and crystallographic orientation is to find a suitable precursor. Putnis et al. ${ }^{[50]}$ showed using ${ }^{18} \mathrm{O}$ tracer that the leucite to analcime reaction proceeds via the ICDR mechanism. Leucite crystals contain inherent 3D ordered networks of nanometer-sized lamellar twins (Fig. 7c and 7e), and Xia et al. ${ }^{[49,51]}$ demonstrat- 

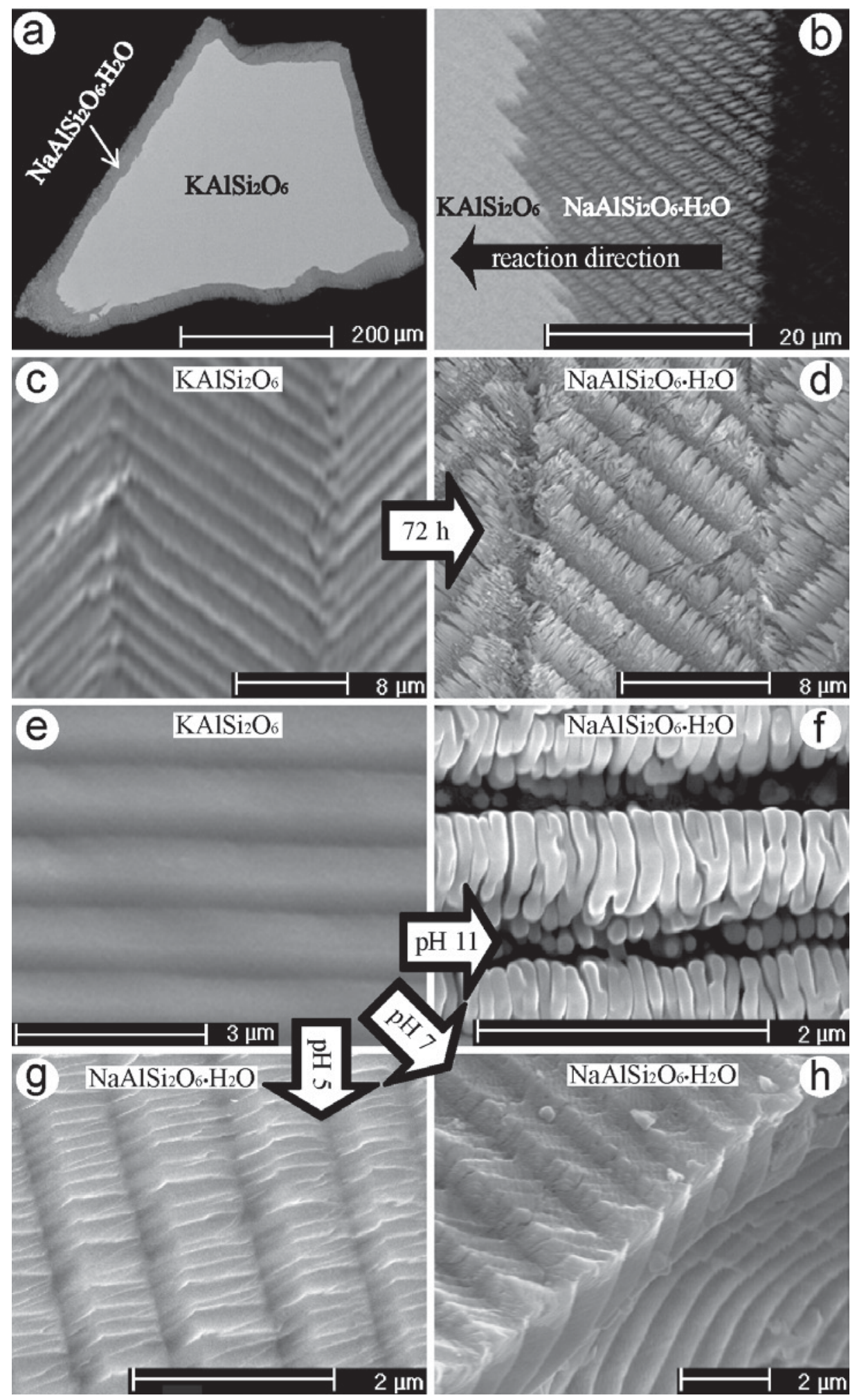

Fig. 7. SEM images of the transformation from leucite $\mathrm{KAISi}_{2} \mathrm{O}_{6}$ to analcime $\mathrm{NaAISi}_{2} \mathrm{O}_{6} \cdot \mathrm{H}_{2} \mathrm{O}$. $(\mathrm{a}, \mathrm{b}) \mathrm{BSE}$ images of partially transformed $\mathrm{KAISi}_{2} \mathrm{O}_{6}$ showing the reaction direction, the preservation of the overall shape, the zigzag sharp reaction front, and the hierarchical porosity in the product phase. (c,d) SE images showing that the 3D ordered arrays of $\mathrm{KAISi}_{2} \mathrm{O}_{6}$ lamellae are preserved in the product, forming 3D ordered arrays of nano $\mathrm{NaAlSi}_{2} \mathrm{O}_{6} \cdot \mathrm{H}_{2} \mathrm{O}$ with uniform size and crystallographic orientation. (e,f) $\mathrm{SE}$ images of $\mathrm{NaAlSi}_{2} \mathrm{O}_{6} \cdot \mathrm{H}_{2} \mathrm{O}$ texture as a function of $\mathrm{pH}$.

ed that such highly ordered 3D patterns could be precisely preserved during hydrothermal pseudomorphic replacement reactions in $\mathrm{pH}$-buffered $\mathrm{NaCl}$ solutions, resulting in $3 \mathrm{D}$ ordered arrays of analcime nanocrystals (Fig. 7d and 7f). Moreover, these analcime nanocrystals have uniform size and crystallographic orientation due to epitaxial nucleation and growth facilitated by the similarity of the crystal lattice between leucite and analcime. The morphology of the nanocrystals is tuneable by simply changing solution $\mathrm{pH}$. Mild acidic to mild alkaline conditions tend to produce cuboid-shaped nanocrystals; while strong alkaline conditions favour the formation of cylindrical-shaped nanocrystals (Fig. 7f-h). The replacement follows the ICDR mechanism, with the dissolution of leucite being rate-limiting.

This pseudomorphic replacement route could be used to synthesize other ordered arrays of functional nanocrystals with controlled shape, size, and crystallographic orientation. Nature provides many possible precursors, but it is also possible to design and synthesize a suitable parent phase. Many minerals, such as microcline, cristobalite, nepheline, sodalite, leucite and other feldspathoid minerals, exhibit a microstructure consisting of a 3D ordered network of twin planes, after a displacive or reconstructive phase transition upon cooling. ${ }^{[52,53]}$ Many such precursors are also readily synthesized mimicking the natural formation environments. ${ }^{[54]}$ Leucite $\left(\mathrm{KAlSi}_{2} \mathrm{O}_{6}\right)$ was used as the precursor to synthesize analcime $\mathrm{NaAlSi}_{2} \mathrm{O}_{6} \cdot \mathrm{H}_{2} \mathrm{O}$ as an illustration of this new synthesis route, ${ }^{[49,51]}$ because leucite crystals are abundant in Nature, and their 3D ordered lamellar twinning has been studied in detail. ${ }^{[55]}$

\section{Conclusions}

CDR reactions are often extremely complex, since they result from a complex dynamic interplay between dissolution and precipitation, controlled critically by phenomena such as surface nucleation, porosity creation/destruction, and transport of aqueous species to and from the reaction front. Understanding the molecular level mechanisms at work in these reactions is key in predicting the textures and compositions of the products, and requires the concerted efforts of physical chemists and mineralogists, but may have many benefits in terms of synthesis of materials with unique chemical and textural properties.

\section{Acknowledgements}

This work is funded by the Australian Research Council Project (DP0878903; DP0772299; DP1095069) and the South Australian Museum. Special thanks are due to the staff at Adelaide Microscopy for their help with scanning electron imaging. We are grateful to T. Armbruster for organising this special volume, and two anonymous reviewers for their helpful comments. This is TRaX publication \#89.

Received: June 8, 2010

[1] J. Brugger, A. Pring, F. Reith, C. Ryan, B. Etschmann, W.H. Liu, B. O'Neill, Y. Ngothai, Radiation Phys. Chem. 2010, 79, 151

[2] A. Putnis, Miner. Mag. 2002, 66, 689 . 
[3] A. Putnis, 'Mineral Replacement Reactions', in 'Thermodynamics and Kinetics of WaterRock Interaction', Reviews in Mineralogy \& Geochemistry, 2009, p. 87.

[4] P. T. Cardew, R. J. Davey, Proc. Royal Soc. 1985, A398, 415.

[5] K. Eda, K. Chin, N. Sotani, M. S. Whittingham, J. Solid State Chem. 2005, 178, 158.

[6] K. Eda, Y. Uno, N. Nagai, N. Sotani, C. Chen, M. S. Whittingham, J. Solid State Chem. 2006, 179, 1453.

[7] A. Putnis, C. V. Putnis, J. Solid State Chem. 2007, 180, 1783

[8] J. Erlebacher, M. J. Azia, A. Karma, N Dimitrov, K. Sieradzki, Nature 2001, 410, 450.

[9] F. Xia, J. Brugger, G.R. Chen, Y. Ngothai, B. O'Neill, A. Putnis, A. Pring, Geochim. Cosmochim. Acta 2009, 73, 1945.

[10] B. Pewkliang, A. Pring, J. Brugger, Can. Miner. 2008, 46, 139.

[11] T. Hagino, Y. Seki, N. Wada, S. Tsuji, T. Shirane, K. Kumagai, S. Nagata, Phys. Rev. 1995, B51, 12673.

[12] S. Nagata, N. Matsumoto, Y. Kato, T Furubayashi, T. Matsumoto, J. P. Sanchez, P. Vulliet, Phys. Rev. 1998, B58, 6844.

[13] M. S. Park, S. K. Kwon, B. I. Min, Phys. Rev. 2001, B64, 100403

[14] C. I. Pearce, R. A. D. Patrick, D. J. Vaughan, Rev. Miner. Geochem. 2006, 61, 127.

[15] D. J. Vaughan, J. R. Craig, 'Mineral chemistry of metal sulfides', Cambridge Univ. Press. UK, 1978.

[16] C. Tenailleau, B. Etschmann, R. M. Ibberson, A. Pring, Amer. Miner. 2006, 91, 1442.

[17] C. Tenailleau, A. Pring, B. Etschmann, J. Brugger, B. Grguric, A. Putnis, Amer. Miner. 2006, $91,706$.

[18] F. Xia, J. Zhou, J. Brugger, Y. Ngothai, B. O'Neill, G. Chen, A. Pring, Chem. Mater. 2008, 20, 2809.

[19] F. Xia, A. Pring, Y. Ngothai, B. O’Neill, J. Brugger, G. Chen, C. Colby, React. Kin. Catal. Lett. 2007, 92, 257.

[20] D. M. Roy, S. K. Linnehan, Nature 1974, 247, 220 .
21] M. Figlarz, B. Gerand, A. Delahayevidal, B. Dumont, F. Harb, A. Coucou, F. Fievet, Solid State Ionics 1990, 43, 143

22] D. O. Henderson, R. Mu, A. Ueda, M. H. Wu, E. M. Gordon, Y. S. Tung, M. Huang, J. Keay, L. C. Feldman, J. A. Hollingsworth, W. E. Buhro, J. D. Harris, A. F. Hepp, R. P. Raffaelle, Mater. Design 2001, 22, 585 .

[23] J. Guha, H.-Z. Lu, B. Dubé, F. Robert, M. Gagnon, Econ. Geol. 1991, 86, 667.

[24] Y. X. Chen, X. He, X. J. Zhao, M. X. Song, X. Y. Gu, Mater. Sci. Eng. B Solid State Mater. Adv Technol. 2007, 139, 88.

[25] P. Guha, D. Das, A. B. Maity, D. Ganguli, S. Chaudhuri, Solar Ener. Mater. Solar Cells 2003 80, 115.

[26] U. Schwarz-Schampera, P. M. Herzig, 'Indium: Geology, Mineralogy, and Economics', Heidelberg, Springer, 2002.

[27] T. Miyauchi, N. Yamamoto, H. Higuchi, Jap. J. Appl. Phys. 2 Lett. 1988, 27, L1178.

[28] S. Gorai, S. Bhattacharya, E. Liarokapis, D. Lampakis, S. Chaudhuri, Mater. Lett. 2005, 59, 3535.

[29] T. Nyari, P. Barvinschi, R. Baies, P. Vlazan, F. Barvinschi, I. Dekany, J. Crys. Growth 2005, 275, e2383.

[30] X. H. Hou, K. L. Choy, Thin Solid Films 2005 480, 13 .

[31] H. M. Pathan, C. D. Lokhande, Appl. Surf. Sci. 2004, 239, 11

[32] I. Oja, M. Nanu, A. Katerski, M. Krunks, A Mere, J. Raudoja, A. Goossens, Thin Solid Films 2005, 480, 82

[33] B. A. Grguric, 'Polymorphism and exsolution in the bornite-digenite solid solution series', unpublished $\mathrm{PhD}$ thesis, Churchill College, University of Cambridge, Cambridge, 1998.

[34] L. Reijnen, B. Meester, A. Goossens, J. Schoonman, Chem. Vapor Deposition 2003, 9, 15 .

[35] Y. B. Lou, A. C. S. Samia, J. Cowen, K. Banger, X. B. Chen, H. Lee, C. Burda, Phys. Chem. Chem. Phys. 2003, 5, 1091.

36] M. Fadden, 'Towards the hydrothermal synthesis of $\mathrm{CuInS}_{2}$ via a coupled dissolution reprecip- itation reaction', unpublished Honours Thesis, University of Flinders, Australia, 2008, 45 pp.

[37] J. P. Vaughan, A. Kyin, Miner. Mag. 2004, 68, 255.

[38] J. Zhao, J. Brugger, P. V. Grundler, F. Xia, G. R. Chen, A. Pring, Amer. Miner. 2009, 94, 1541.

[39] J. Zhao, F. Xia, A. Pring, J. Brugger, P. Grundler, G. Chen, Miner. Eng. 2010, online 23 December 2009.

[40] J. M. Thomas, W. J. Thomas, 'Principles and practice of heterogeneous catalysis', 1997, New York, Wiley-VCH, 1997.

[41] C. S. Cundy, P. A. Cox, Chem. Rev. 2003, 103, 663.

[42] L. Tosheva, V. P. Valtchev, Chem. Mater. 2005, 17, 2494.

[43] M. A. Snyder, M. Tsapatsis, Angew. Chem. Int. Ed. 2007, 46, 7560

[44] M. E. Davis, Nature 2002, 417, 813

[45] R. Srivastava, M. Choi, R. Ryoo, Chem. Commun. 2006, 43, 4489.

[46] K. H. Rhodes, S. A. Davis, F. Caruso, B. J Zhang, S. Mann, Chem. Mater. 2000, 12, 2832.

[47] M. W. Anderson, S. M. Holmes, N. Hanif, C. S. Cundy, Angew. Chem. Int. Ed. 2000, 39, 2707.

[48] G. Calzaferri, K. Lutkouskaya, Photochem. Photobiol. Sci. 2008, 7, 879.

[49] F. Xia, J. Brugger, Y. Ngothai, B. O’Neill, G. R. Chen, A. Pring, Crys. Growth Design 2009, 9 , 4902.

[50] C. V. Putnis, T. Geisler, P. Schmid-Beurmann, T. Stephan, C. Giampaolo, Amer. Miner. 2007, 92, 19.

[51] F. Xia, B. O'Neill, Y. Ngothai, J. Peak, C. Tenailleau, B. Etschmann, G. Qian, J. Brugger, A. Studer, S. Olsen, A. Pring, J. Appl. Crys. 2010, 43.

[52] A. Putnis, 'Introduction to mineral sciences', Cambridge University Press, 1992.

[53] W. A. Deer, R. A. Howie, J. Zussman, 'An introduction to the rock-forming minerals', 2nd ed. Essex, Longman, 1996.

[54] Y. Zhang, J. Wu, P. Rao, M. Lv, Mater. Lett. 2006, 60, 2819

[55] D. C. Palmer, A. Putnis, E. K. H. Salje, Phys. Chem. Miner. 1988, 16, 298. 